\title{
Effect of soil type on chemical composition and antioxidant properties of Solanum nigrum (L.) shoot oil extracts
}

\author{
Adijat F Ogundola, Callistus Bvenura, Anthony J Afolayan \\ Medicinal Plants and Economic Development Research Centre, University of Fort Hare, P Bag X1314, Alice, 5700, South Africa
}

*For correspondence: Email: aafolayan@ufh.ac.za; Tel: +27-822022167

Sent for review: 18 March 2017

Revised accepted: 22 March 2021

\begin{abstract}
Purpose: To investigate the effect of different soil textures on chemical composition and antioxidant properties of essential oils from Solanum nigrum.

Methods: Four soils of differing texture were formulated from soil under fallow to cultivate S. nigrum in a glasshouse. Essential Oil was extracted from fresh shoots by solvent-free microwave extraction (SFME) and analysed using gas chromatography-mass spectrometry (GC-MS). Antioxidant properties were assayed (DPPH) and ABTS

Results: GC-MS profiling revealed variations in the quality index (QI), number of chemical constituents and antioxidant results of S. nigrum oil. Geraniol and citronellol were the two principal components. The highest activity of the antioxidant was found in plants cultivated on clay loam soil. Fifty percent (50\%) Inhibitory Concentration (IC $C_{50}$ ) ranged from 1.196 to $1.594 \mu \mathrm{g} / \mathrm{mL}$ and 0.067 to $3.59 \mu \mathrm{g} / \mathrm{mL}$ in DPPH and ABTS assays, respectively.

Conclusions: This research work indicates that soil texture influences the oil quality, quantity and chemical composition of oil extracted from S. nigrum shoots. Essential oil extracts from S. nigrum grown on clay loam soils recorded the highest antioxidant properties.
\end{abstract}

Keywords: Soil types, Essential oil, Solanum nigrum, Antioxidant properties

This is an Open Access article that uses a fund-ing model which does not charge readers or their institutions for access and distributed under the terms of the Creative Commons Attribution License (http://creativecommons.org/licenses/by/4.0) and the Budapest Open Access Initiative (http://www.budapestopenaccessinitiative.org/read), which permit unrestricted use, distribution, and reproduction in any medium, provided the original work is properly credited.

Tropical Journal of Pharmaceutical Research is indexed by Science Citation Index (SciSearch), Scopus, International Pharmaceutical Abstract, Chemical Abstracts, Embase, Index Copernicus, EBSCO, African Index Medicus, JournalSeek, Journal Citation Reports/Science Edition, Directory of Open Access Journals (DOAJ), African Journal Online, Bioline International, Open-J-Gate and Pharmacy Abstracts

\section{INTRODUCTION}

The folkloric use of nutraceutical medicinal plants has put further declaration on the importance of plants in human health. The report that diseases such as cancer, hepatotoxicity and others can be controlled if or when antioxidants, normally from natural plant foods or products are assimilated is highly encouraging [1]. Other reports have also confirmed the ability of rich antioxidant containing food of plant origin in the prevention of cancer. The bioactive compounds in the plants have been confirmed better and with fewer side effects when compared to the chemically synthesised compounds [2]. So therefore, the effectiveness of these compounds may be considered for use in both chemoprevention and chemotherapy of cancer [3]. All encouraging pieces of information on biomedical activities of plants gave the insight 
that the essential oil could be another means of exploring the plants.

The use of essential oils in food and cosmetic products is widespread and on demand. However, the biological functions of essential oils depend on the chemical composition of the oil and these vary with part of plant, method of extraction, age and environmental conditions [4]. Therefore, there is still need for further search for more important plants especially those with nutraceutical values to exploit them for essential oil with different bioactive compounds.

Solanum nigrum (Black nightshade); is an aromatic plant with an unsatisfactory odour, however with successful reports as a medicinal plant [5]. Medicinal aromatic plants have been reported in the treatment of HIV / AIDS, malaria, diabetes, sickle-cell anaemia and microbial infections [6]. So also, many studies have reported cancer preventive potentials of oil extracted from aromatic plants with their efficacies tied on their antioxidant properties [7]. The plant has been extensively used in the folkloric treatment of chronic diseases and ailments. Crowning the information about the plant is the notable report of its anticancer properties documented by [8].

Variations in the quality and chemical composition of essential oils extracted from the same plant have been reported and these may result from factors such as geo-climatic location, growing season, and growing conditions [9]. However, soil types on which the plant is grown is another environmental factor that has not been reported, the gap considered to be filled by this study. The focus of this study is therefore, to investigate the effect of soil texture types on the chemical composition and antioxidant properties of essential oils from the shoot parts of cultivated S. nigrum.

\section{EXPERIMENTAL}

\section{Soil collection and treatments}

The soil was collected from a fallow land at a depth of $30 \mathrm{~cm}$ from the University of Fort Hare farm, Alice campus in South Africa located at $32^{\circ} 46^{\prime} 47^{\prime \prime} S$ and $26^{0} 50^{\prime} 5^{\prime \prime} E$ and $524 \mathrm{~m}$ a.s.l. Soil treatments were relative combinations of sand, silt and clay in different proportions according to the classification system by [10], using soil texture triangle rules.

The physical composition of the relative combined soil types on which $S$. nigrum was cultivated is presented as follows on Table 1.
Table 1: Textural composition of experimental soils

\begin{tabular}{l|ccc}
\hline Soil type & $\begin{array}{c}\text { Sand } \\
\text { particle } \\
(\%)\end{array}$ & $\begin{array}{c}\text { Silt } \\
\text { particles } \\
(\%)\end{array}$ & $\begin{array}{c}\text { Clay } \\
\text { particles } \\
(\%)\end{array}$ \\
\hline $\begin{array}{l}\text { Control } \\
\mathrm{ST}_{0}\end{array}$ & 60 & 30 & 10 \\
$\begin{array}{l}\text { Sandy } \\
\text { clay loam }\end{array}$ & 66 & 13 & 21 \\
$\mathrm{ST}_{1}$ & & & \\
$\begin{array}{l}\text { Silty clay } \\
\text { loam ST }\end{array}$ & 10 & 60 & 30 \\
$\mathrm{Clay} \mathrm{loam}_{\mathrm{ST}}$ & 36 & 30 & 34 \\
Loam ST $_{4}$ & 40 & 40 & 20 \\
\hline
\end{tabular}

The content of $\mathrm{Ca}, \mathrm{K}, \mathrm{Mg}, \mathrm{Na}$ and $\mathrm{P}$ was determined using the Inductively Coupled Plasma - Optical Emission Spectrometer [11]. The soil results were garnished on Tables 2 .

\section{Plant collection and identification}

Seeds were obtained from mature berries of plants by hand squeezing, washing in distilled water and air-dried for 3 days and planted in nursery trays in the green house. Seedlings of $S$. nigrum were transplanted at 4 leaf stage into experimental pots containing different soil texture nutrient compositions Table 1. The trial was conducted between February and March, 2016 at the University of Fort Hare, Alice campus, Eastern Cape, South Africa, located at $32^{\circ} 46^{\prime} 47^{\prime \prime} S$ and 2650' 5"'E and 524m a.s.l. The plant had earlier been identified (BVE11/017) and deposited at the Giffen herbarium of the same University. For this study, S. nigrum cultivated on different soil types, were harvested at the early flowering stage ( $4^{\text {th }}$ week) from each of the soil types in the green house, at the Faculty of Agriculture, University of Fort Hare. The freshly collected samples were separated into shoot and root parts, air dried and weighed.

\section{Solvent-free microwave extraction (SFME)}

About $315 \mathrm{~g}$ fresh shoot samples of $S$. nigrum were differently placed into the reactor without addition of water or solvent. Oils were obtained by Solvent Free Microwave Extraction (SFME) using Milestone Dry DIST (2004) apparatus. Incorporated in multimode reactor is a twin magnetron (2 x $800 \mathrm{~W}, 2450 \mathrm{MHz})$ having maximum delivered power of $500 \mathrm{~W}$ in $5 \mathrm{~W}$ increments. Homogeneous microwave distribution was achieved by a rotating microwave diffuser throughout the plasma coated PTFE cavity. An external infrared sensor monitored the temperature and the temperature constant conditions and water were guaranteed by the reflux of the condensed water which was achieved at $5^{0} \mathrm{C}$ by a circulating cooling system. 
The extraction got complete in 40 minutes. Essential oil was collected in air tight bottles and stored in the refrigerator at $4{ }^{\circ} \mathrm{C}$ before analysis [12]. The oils were qualitatively and quantitatively analysed with Gas Chromatography-Mass Spectrometry.

\section{Gas chromatography-mass spectrometry (GC-MS)}

Oil samples were analysed using coupled Agilent 5975 and Agilent 6890 MSD with a Zebron- 5MS column (ZB-5MS $30 \mathrm{~m} \times 0.25 \mu \mathrm{m}$ ) 5\%-phenyl methyl polysiloxane). A carrier gas of $\mathrm{GC}$ grade helium at a flow rate of $2 \mathrm{ml} / \mathrm{min}$ was used. Split less $1 \mu$ injections for analysis. Injector temp was $280{ }^{\circ} \mathrm{C}$; source temp was $280{ }^{\circ} \mathrm{C}$. Oven temp $70^{\circ} \mathrm{C}$, ramp at $15^{\circ} \mathrm{C} / \mathrm{min}$ to $120^{\circ} \mathrm{C}$, ramp at $10{ }^{\circ} \mathrm{C} / \mathrm{min}$ to $180{ }^{\circ} \mathrm{C}$ then ramp at $20{ }^{\circ} \mathrm{C} / \mathrm{min}$ to $270{ }^{\circ} \mathrm{C}$ hold for 3 mins. Data were gathered with Chem station.

Determination of effect of soil type on antioxidant properties of essential oil

Antioxidant radical screening of $S$. nigrum shoot oil from different soil types were investigated using the 1, 1-diphenyl-2-picryl-hydrazyl (DPPH) and 2, 2'-azino-bis (3-ethylbenzthiazoline-6sulfonic acid (ABTS).

\section{DPPH assay}

Free radical scavenging activity measured in $\mathrm{DPPH}$ assay was achieved by adopting the method of Odeyemi et al [13]. It followed a concentration dependent pattern $(0.025,0.5,0.1$, $0.2,0.4) \mu \mathrm{g} / \mathrm{ml}$. $1.0 \mathrm{ml}$ was prepared in a solution of $0.135 \mathrm{mM}$ DPPH radical methanol. $1 \mathrm{ml}$ of this solution was mixed with $\beta$-carotene and vitamin $C$ separately. The reaction mixture was vortexed thoroughly and left in the dark at room temperature for $30 \mathrm{~min}$. Absorbance was measured spectrophotometrically at $517 \mathrm{~nm}$. The actual decrease in absorbance was measured against $\beta$-carotene and ascorbic acid (AA) as standards. DPPH scavenging ability (D) was then calculated using Eq 1.

$D(\%)=\{A c-A s) / A c\} 100$

where Ac and As are the absorbance of control and test samples, respectively.

\section{ABTS assay}

ABTS radical scavenging activity was achieved using the method described by Kibiti and Afolayan [14 Stock solutions of essential oils of S. nigrum were prepared following a concentration dependent pattern $(0.025,0.5,0.1$, $0.2,0.4) \mu \mathrm{g} / \mathrm{ml}$. Briefly, the stock solutions of 7 $\mathrm{mM}$ ABTS solution and $2.4 \mathrm{mM}$ potassium persulfate solution were prepared separately. Mixture of equal ratios $1: 1 \mathrm{v} / \mathrm{v}$ of the two solutions was prepared and allowed to react for $12 \mathrm{~h}$ in the dark at room temperature. The solution was then diluted by mixing $1 \mathrm{~mL}$ ABTS + solution with $60 \mathrm{~mL}$ of methanol to obtain an absorbance of $0.708 \pm 0.001$ units at $734 \mathrm{~nm}$ using the spectrophotometer. The oil extracts (1 $\mathrm{mL}$ ) and their controls were allowed to react with $1 \mathrm{~mL}$ of the ABTS + solution for $7 \mathrm{~min}$. The decrease of absorption was measured at $734 \mathrm{~nm}$ in a cuvette with the spectrophotometer. The ABTS + scavenging capacity of the oil extract was then compared with those of the standards. Inhibition $(\mathrm{H})$ of ABTS was calculated as in Eq 2.

$H(\%)=\left[1-\frac{\text { Abs sample }}{\text { shr f คntrnil }}\right] \times 100$

where Abs sample and Abs control are the absorbance of test and control samples, respectively.

\section{Statistical analysis}

All data were subjected to statistical analysis using Minitab, version 17. One-way analysis of variance (ANOVA) was used to compare the mean values among soil treatments. Means were separated using Fisher's least significant difference (LSD) paired wise comparison and taken as significantly different at $p<0.05$.

\section{RESULTS}

\section{Effect of soil type on chemical composition of essential oil}

Microwave extraction of fresh shoot part of $S$. nigrum yielded $0.2,0.3,0.4,0.4,0.3 \%(\mathrm{v} / \mathrm{w})$ essential oils from the control, sandy clay loam, silty clay loam, clay loam and loam soil respectively. The chemical compounds from GCMS analysis of the volatile oil from $S$. nigrum samples were identified from different soil types. The components were characterized by a mass spectral survey using the NIST mass spectral search program and GC-MS Library. Comparison was made on calculated Kovat retention indices (RI) of oils from different soil types with those already cited in literature [15]. The various constituent percentage compositions, molecular formulae, molecular weight and retention time are shown on Table 3. Compounds found in oils extracted from $S$. nigrum shoot samples from different soil types are presented in Table 3 . The GC-MS analysis resulted in identification of 13 to 16 compounds in S. nigrum. These compounds 
were representing $87.9,93.8,96,99.1$ and $78 \%$ of the total oil composition of $S$. nigrum shoot samples from the control, sandy clay loam, silty clay loam, clay loam and loam soil types respectively. The general chemical profile of fractions, the percentage contents and the retention indices of the constituents are summarized in Table 3. Principal constituents of $S$. nigrum shoot oil samples from different studied soil types were: citronellol, geraniol, citronellyl tiglate and geraniol tiglate, which were of high-quality index (83- $99 \%)$. The compounds reported in the different soil types decreased in the order: $\mathrm{ST}_{3}>\mathrm{ST}_{2}>\mathrm{ST}_{1}>\mathrm{ST}_{0}>\mathrm{ST}_{4}$ as shown in Table 3.

Generally, in this study, regardless of the soil types, the major compounds found in the essential oils could be classified as terpenoids, esters and hydrocarbons [16]. Highest geraniol and citronellol levels were recorded forclay loam soil (Table 3).

Citronellol was the second principal compound after geraniol in the essential oil of $S$. nigrum cultivated in different soil types and they are both known for defence mechanisms [17].

\section{Effect of soil type on DPPH radical scavenging activity of essential oil}

The free radical scavenging activity increased with increase in oil concentration ranging from 61.16 to $79.70 \%$ (Table 4). In all the working concentrations, all the treatments competed favourably with the two standards, $\beta$-carotene and vitamin $C$. However, the highest radical scavenging value was reached by plants cultivated on clay loam soil which also compared favourably well with $\beta$-carotene and vitamin $C$ as shown in Table 4. Moreover, the $\mathrm{IC}_{50}$ value of $1.196-1.594 \mu \mathrm{g} / \mathrm{ml}$ is an indication that $S$. nigrum had high antioxidant activity. However, the positive controls, vitamin $C$ and $\beta$-carotene, showed an $\mathrm{IC}_{50}$ value of 0.7224 and $0.8430 \mu \mathrm{g}$ $/ \mathrm{ml}$, respectively. From the current study, clay loam soil $\left(\mathrm{ST}_{3}\right)$ recorded the highest $\mathrm{IC}_{50}$ value $(1.9594 \mu \mathrm{g} / \mathrm{ml})$ while loam soil recorded the lowest value $(1.252 \mu \mathrm{g} / \mathrm{ml})$; the lowest value indicates the best treatment (Table 4).

Effect of soil type on ABTS radical
scavenging activity of essential oil

ABTS radical scavenging activity increased from 41.86 to $67.23 \%$ as the concentrations increased as shown in Table 5. At all working concentrations, all treatments appeared to have competed favourably with the two standards used (BHT and vitamin $\mathrm{C}$ ). At lower concentrations $(0.025-0.100 \mathrm{mg} / \mathrm{mL})$, oil extract treatments compared favourably and better than the two standards BHT and vit $\mathrm{C}$. At higher concentrations $(0.2$ and $0.4 \mathrm{mg} / \mathrm{mL})$, the two standards exhibited higher radical scavenging power but oil extracts from clay loam (ST3) showed higher radical scavenging power than $\mathrm{BHT}$ but still compared well with vitamin $\mathrm{C}$ at 0.2 $\mathrm{mg} / \mathrm{mL}$. However, vitamin $\mathrm{C}$ exhibited higher radical scavenging power than $\mathrm{BHT}$. Clay loam soil has the highest significant $(p>0.05)$ radical scavenging activity when compared with the control soil and the two standards. The two standards showed higher radical scavenging power than all the oil treatments. However, from 0.1 to $0.4 \mathrm{mg} / \mathrm{mL}$ concentrations, oil extracts from silty clay loam and loam soil showed higher radical scavenging power than $50 \%$ of the ABTS standard and the highest value $(67.23 \%)$ was reached by the extract cultivated on clay loam soil as shown in Table 6 . The $I_{50}$ range from 0.067 to $3.59 \mu \mathrm{g} / \mathrm{mL}$ is a good indicator of good scavenging power of $S$. nigrum (Table 6).

\section{DISCUSSION}

Disparity in the number, types and quality of chemical components in essential oils from shoot extracts of $S$. nigrum established that soil texture has an influence on the volatile oil synthesised. The presence of geraniol and citronellol (monoterpenes) in $S$. nigrum as an aromatic plant agree with the report of Singh et al [18]. High contents of geraniol and citronellol as the principal constituents in the oils may be responsible for the antioxidant properties of $S$. nigrum. The potency of this plant in folkloric treatment of chronic ailments and the antioxidant results of the essential oils in this study agree with the report that geraniol as an acyclic monoterpene alcohol, exerts a broad spectrum of pharmacological activities like anti-inflammatory, antioxidant, anti-ulcers and neuroprotective activities [19].

Carnesecchi et al [20] demonstrated that geraniol (monoterpene) sensitized human colonic cancer cells to 5-fluorouracil treatment in vitro, a mechanism related to its antioxidant properties. The results from some previous authors confirmed the presence of geraniol in $S$. nigrum which has been known for its potential role in the treatment of different types of cancers such as breast, colon, lung, prostate, pancreatic and hepatic toxicity [16].

In the present study, higher radical scavenging activity and lower $\mathrm{IC}_{50}$ values recorded in DPPH and ABTS scavenging activity could be due to the presence of geraniol and citronellol in the 
Table 2: Chemical composition of the soils before the trial

\begin{tabular}{|c|c|c|c|c|c|c|c|c|c|c|c|c|c|}
\hline \multirow[b]{2}{*}{ Soil types } & \multirow[b]{2}{*}{$\mathbf{P}$} & \multirow[b]{2}{*}{$\mathbf{K}$} & \multicolumn{3}{|c|}{ Content (mg/kg) } & \multirow[b]{2}{*}{$\mathrm{Zn}$} & \multirow[b]{2}{*}{ Mn } & \multirow[b]{2}{*}{$\mathrm{Cu}$} & \multirow[b]{2}{*}{$\begin{array}{l}\text { Org. } \\
\text { cont } \%\end{array}$} & \multirow[b]{2}{*}{$\mathrm{pH}$} & \multirow[b]{2}{*}{ Clay \% } & \multirow[b]{2}{*}{ Sand \% } & \multirow[b]{2}{*}{ Silt \% } \\
\hline & & & $\mathbf{N}$ & $\mathrm{Ca}$ & Mg & & & & & & & & \\
\hline $\mathrm{ST}_{0}$ & $68^{\mathrm{b}} \pm 1$ & $524^{\mathrm{a}} \pm 0$ & $3.4^{c} \pm 1$ & $1389^{a} \pm 0.5$ & $332^{\mathrm{b}} \pm 0.1$ & $6.0^{\mathrm{b}} \pm 0.3$ & $29^{d} \pm 1$ & $10.5^{c} \pm 0$ & $4^{\mathrm{C}} \pm 0.5$ & $6.22^{\mathrm{a}} \pm 0$ & $10^{\mathrm{c}} \pm 1$ & $60^{a} \pm 1$ & $30^{c} \pm 1$ \\
\hline $\mathrm{ST}_{1}$ & $84^{\mathrm{a}} \pm 0$ & $467^{d} \pm 1$ & $3.6^{c} \pm 0$ & $1357^{\mathrm{b}} \pm 0.5$ & $347^{a} \pm 0.5$ & $8.1^{a} \pm 0.5$ & $66^{a} \pm 0$ & $15.6^{a} \pm 0$ & $3.9^{c} \pm 0$ & $5.7^{\mathrm{b}} \pm 1$ & $21^{b} \pm 1$ & $66^{a} \pm 0.5$ & $13^{\mathrm{d}} \pm 0$ \\
\hline $\mathrm{ST}_{3}$ & $60^{\mathrm{cd}} \pm 0$ & $519^{b} \pm 1$ & $4.8^{b} \pm 0$ & $1318^{c} \pm 1.0$ & $321^{c} \pm 0.0$ & $5.3^{c} \pm 0.1$ & $38^{c} \pm 0$ & $10.3^{c} \pm 0$ & $4.5^{\mathrm{b}} \pm 0$ & $5.63^{b} \pm 1$ & $34^{a} \pm 0$ & $10^{c} \pm 1$ & $30^{c} \pm 0.1$ \\
\hline $\mathrm{ST}_{4}$ & $63^{c} \pm 1$ & $482^{c} \pm 0$ & $4.6^{b} \pm 0$ & $1290^{d} \pm 0.5$ & $330^{\mathrm{b}} \pm 0.5$ & $6.2^{b} \pm 0$ & $45^{\mathrm{b}} \pm 0$ & $11.4^{\mathrm{b}} \pm 0$ & $4.8^{\mathrm{a}} \pm 1$ & $5.63^{b} \pm 0$ & $20^{\mathrm{b}} \pm 1$ & $40^{\mathrm{b}} \pm 1$ & $40^{\mathrm{b}} \pm 0$ \\
\hline
\end{tabular}

Values shown are mean \pm standard deviation (SD); Different letters down a column represent significant differences at $p<0.05$; different letters denote significant differences among the soil types $\mathrm{ST}_{0}, \mathrm{ST}_{1}, \mathrm{ST}_{2}, \mathrm{ST}_{3}$ and $\mathrm{ST}_{4}$; letters that represents significant differences are from up ST0 column down the ST4 column for each of the measured parameters 
Ogundola et al

Table 3: Effect of soil types on chemical composition of essential oils from S. nigrum shoots

\begin{tabular}{|c|c|c|c|c|c|c|c|c|c|c|c|c|c|c|c|c|c|}
\hline \multirow[t]{2}{*}{ Compound } & \multicolumn{3}{|l|}{ Soil type } & \multicolumn{3}{|l|}{$\mathbf{S T}_{0}$} & \multicolumn{4}{|l|}{$\mathrm{ST}_{1}$} & \multicolumn{2}{|c|}{$\mathbf{S T}_{2}$} & \multicolumn{2}{|c|}{$\mathrm{ST}_{3}$} & \multicolumn{3}{|c|}{$\mathrm{ST}_{4}$} \\
\hline & $M F$ & $M M$ & $K I$ & $R T$ & $\% A$ & $K I$ & $R T$ & $\% A$ & $K I$ & $R T$ & $\% A$ & $K I$ & $R T$ & $\% A$ & $K I$ & $R T$ & $\% A$ \\
\hline Geraniol & $\mathrm{C}_{10} \mathrm{H}_{18} \mathrm{O}$ & 154 & 1061 & 6.4 & 26.3 & 1057 & 6.3 & 31.3 & 1051 & 6.2 & 31.5 & 1061 & 6.4 & 22.4 & 1051 & 6.2 & 31.7 \\
\hline Citronellol & $\mathrm{C}_{10} \mathrm{H}_{20} \mathrm{O}$ & 156 & 1051 & 6.2 & 13.0 & 1062 & 6.4 & 19.1 & 1061 & 6.4 & 15.1 & 1051 & 6.2 & 39.5 & 1061 & 6.4 & 17.9 \\
\hline Citral & $\mathrm{C}_{10} \mathrm{H}_{16} \mathrm{O}$ & 152 & 847.7 & 2.1 & 2.1 & - & - & - & - & - & - & 1061 & 6.4 & 0.9 & 1061 & 6.4 & 0.9 \\
\hline Geraniol butyrate & $\mathrm{C}_{14} \mathrm{H}_{24} \mathrm{O}$ & 208.3 & - & - & - & - & - & - & - & - & - & 1166 & 8.5 & 2.9 & - & - & - \\
\hline Phytol & $\mathrm{C}_{20} \mathrm{H}_{40} \mathrm{O}$ & 296.5 & 1233 & 11.4 & 3.3 & - & - & - & - & - & - & - & - & - & - & - & - \\
\hline Phenyl ester & $\mathrm{C}_{10} \mathrm{H}_{12} \mathrm{O}_{2}$ & 164.2 & 1176 & 8.7 & 6.7 & 1176 & 8.7 & 6.3 & - & - & - & - & - & - & - & - & - \\
\hline Neryl acetate & $\mathrm{C}_{12} \mathrm{H}_{20} \mathrm{O}$ & 196.3 & 1299 & 7.9 & 2.0 & - & - & - & 1299 & 7.9 & 2.9 & - & - & - & 1138 & 8.0 & 2.3 \\
\hline Trans citral & $\mathrm{C}_{10} \mathrm{H}_{16} \mathrm{O}$ & 152.2 & 1071 & 6.6 & 2.1 & 1071 & 6.6 & 3.0 & - & - & - & - & - & - & - & - & - \\
\hline Fumaric acid & $\mathrm{C}_{4} \mathrm{H}_{4} \mathrm{O}_{4}$ & 116.1 & - & 10.2 & 1.5 & - & - & - & - & - & - & - & - & - & - & - & - \\
\hline Geranyl tiglate & $\mathrm{C}_{15} \mathrm{H}_{24} \mathrm{O}_{2}$ & 236.3 & 1172 & 9.3 & 9.3 & 1171 & 9.3 & 7.2 & 1172 & 9.3 & 6.7 & 1172 & 9.3 & 4.8 & 1172 & 9.3 & 4.9 \\
\hline Citronellyl tiglate & $\mathrm{C}_{15} \mathrm{H}_{26} \mathrm{O}_{2}$ & 238.4 & 1163 & 9.1 & 3.8 & 1163 & 9.1 & 3.1 & 1163 & 9.1 & 2.9 & 1163 & 9.1 & 2.3 & 1163 & 9.1 & 2.1 \\
\hline Phenylethyl tiglate & $\mathrm{C}_{13} \mathrm{H}_{16} \mathrm{O}_{2}$ & 204.3 & - & - & - & - & - & - & 64 & 8.7 & 5.7 & 866.9 & 8.7 & 4.0 & - & - & - \\
\hline Caryophylene oxide & $\mathrm{C}_{15} \mathrm{H}_{24} \mathrm{O}$ & 220.4 & 650.4 & 8.8 & 6.3 & 1150 & 8.8 & 5.8 & 650.4 & 8.8 & 6.3 & 650.4 & 8.8 & 5.4 & - & - & - \\
\hline Methyl naphthalene & $\mathrm{C}_{15} \mathrm{H}_{24}$ & 204.4 & 1159 & 9.0 & 2.9 & - & - & - & 1159 & 9.0 & 2.4 & - & - & - & - & - & - \\
\hline Cyclohexene & $\mathrm{C}_{6} \mathrm{H}_{10}$ & 82.1 & - & - & - & - & 9.0 & 2.4 & - & - & - & - & - & - & - & - & - \\
\hline Tetracosane & $\mathrm{C}_{24} \mathrm{H}_{50}$ & 338.7 & 97 & 12.2 & 1.0 & - & - & - & - & - & - & - & - & - & - & - & - \\
\hline Eicosane & $\mathrm{C}_{20} \mathrm{H}_{42}$ & 282.6 & 1227 & 11.3 & 1.4 & 1227 & 11.3 & 1.1 & - & - & - & - & - & - & - & - & - \\
\hline Geranyl acetate & $\mathrm{C}_{2} \mathrm{H}_{3} \mathrm{O}_{2}$ & 59.0 & - & - & - & - & 7.3 & 0.9 & - & 6.8 & 4.6 & - & 7.3 & 0.1 & - & 7.3 & 1.6 \\
\hline Geranyl vinyl ether & $\mathrm{C}_{12} \mathrm{H}_{20} \mathrm{O}$ & 180.3 & - & - & - & - & - & - & - & - & - & 1090 & 6.8 & 2.9 & - & - & - \\
\hline Heptachlor & $\mathrm{C}_{10} \mathrm{H}_{5} \mathrm{C}_{17}$ & 373.3 & - & - & - & - & - & - & - & - & - & 1251 & 10.2 & 0.7 & - & - & - \\
\hline Propanoic acid & $\mathrm{C}_{3} \mathrm{H}_{6} \mathrm{O}_{2}$ & 74.1 & - & - & - & - & - & - & - & - & - & - & - & - & - & - & - \\
\hline Butanoic acid & $\mathrm{C}_{4} \mathrm{H}_{8} \mathrm{O}_{2}$ & 96.2 & - & 8.5 & 4.5 & - & 12.1 & 5.6 & - & 8.5 & 4.3 & - & 8.5 & 2.8 & - & - & - \\
\hline Ethyl carbonate & $\mathrm{C}_{5} \mathrm{H}_{10} \mathrm{O}_{3}$ & 118.1 & - & 8.3 & 1.7 & - & 8.3 & 1.7 & - & 7.9 & 1.4 & - & - & - & - & 8.0 & 0.8 \\
\hline $\begin{array}{l}\text { Trans-sequisabenene } \\
\text { hydrate }\end{array}$ & $\mathrm{C}_{15} \mathrm{H}_{26} \mathrm{O}$ & 222.4 & - & - & - & - & - & - & - & - & - & - & - & - & 659.1 & 9.0 & 0.8 \\
\hline Geranyl formate & $\mathrm{C}_{11} \mathrm{H}_{18} \mathrm{O}$ & 182.3 & - & - & - & 975.7 & 6.6 & 6.3 & 1080 & 6.7 & 5.5 & 1075 & 6.6 & 9.2 & 957.7 & 6.6 & 9.2 \\
\hline Citronellyl formate & $\mathrm{C}_{11} \mathrm{H}_{20} \mathrm{O}_{2}$ & 184.3 & - & - & - & - & - & - & 975.7 & 6.6 & 6.3 & - & - & - & 984.2 & 6.8 & 5.0 \\
\hline 3-octadecene & $\mathrm{C}_{18} \mathrm{H}_{36}$ & 252.5 & - & - & - & - & - & - & 338.6 & 10.2 & 0.8 & - & - & - & - & - & - \\
\hline Citronellyl cinnamate & $\mathrm{C}_{19} \mathrm{H}_{28} \mathrm{O}_{2}$ & 286.4 & - & - & - & - & - & - & - & - & - & 1021 & 8.0 & 1.8 & - & - & - \\
\hline Isobutyl carbonate & $\mathrm{C}_{9} \mathrm{H}_{18} \mathrm{O}_{3}$ & 174.2 & - & - & - & - & - & - & - & - & - & - & - & - & - & 9.4 & 0.9 \\
\hline Carboxyethane/ Luprisol & $\mathrm{C}_{3} \mathrm{H}_{6} \mathrm{O}_{2}$ & 74.1 & - & - & - & - & - & - & - & - & - & - & - & - & - & 10 & 0.8 \\
\hline Total $\%$ oil content & & & & & 87.9 & & & 93.8 & & & 96.4 & & & 99.1 & & & 78.9 \\
\hline
\end{tabular}


Table 4: Effect of soil type on DPPH radical scavenging activity on S. nigrum shoot oil extract

\begin{tabular}{|c|c|c|c|c|c|c|c|}
\hline $\begin{array}{l}\text { Oil conc } \\
\mu \mathrm{g} / \mathrm{ml}\end{array}$ & $\mathbf{S T}_{0}$ & $\mathrm{ST}_{1}$ & $\mathrm{ST}_{2}$ & $\mathrm{ST}_{3}$ & $\mathrm{ST}_{4}$ & B Caro & Vit. C \\
\hline 0.025 & $62 \pm 0.03$ & $64.2 \pm 0.13$ & $65.1 \pm 0.19$ & $66.2 \pm 0.27$ & $64.3 \pm 0.14$ & $33.6 \pm 0.21$ & $23.8 \pm 2.7$ \\
\hline 0.05 & $65.8 \pm 0.24$ & $66.1 \pm 0.26$ & $66.6 \pm 0.3$ & $72.1 \pm 0.68$ & $65.8 \pm 0.24$ & $51.8 \pm 0.74$ & $26.3 \pm 2.52$ \\
\hline 0.1 & $66.9 \pm 0.32$ & $67.4 \pm 0.35$ & $68.2 \pm 0.41$ & $74 \pm 0.81$ & $66.1 \pm 0.26$ & $52.9 \pm 0.66$ & $28.8 \pm 2.35$ \\
\hline 0.2 & $66.5 \pm 0.29$ & $69 \pm 0.46$ & $69.5 \pm 0.5$ & $76.3 \pm 0.97$ & $68.4 \pm 0.42$ & $69.4 \pm 0.49$ & $46.8 \pm 1.09$ \\
\hline 0.4 & $68.8 \pm 0.45$ & $72.1 \pm 0.68$ & $75.9 \pm 0.95$ & $78.1 \pm 1.1$ & $72.4 \pm 0.7$ & $77.5 \pm 1.06$ & $54.2 \pm 0.57$ \\
\hline
\end{tabular}

Table 5: Effect of soil types on ABTS radical scavenging activity on S. nigrum oil extract

\begin{tabular}{llllllll}
\hline $\begin{array}{l}\text { Oil conc } \\
\mu \mathbf{g} / \mathbf{m l}\end{array}$ & $\mathbf{S T}_{\mathbf{0}}$ & $\mathbf{S T}_{1}$ & $\mathbf{S T}_{\mathbf{2}}$ & $\mathbf{S T}_{\mathbf{3}}$ & $\mathbf{S T}_{\mathbf{4}}$ & $\mathbf{B H T}$ & Vit. C \\
\hline $0.025 \pm$ & $42.5 \pm 0.03$ & $41.8 \pm 0.04$ & $43 \pm 0.03$ & $44 \pm 0.02$ & $42 \pm 0.04$ & $22.5 \pm 0.01$ & $26 \pm 0.01$ \\
$0.05 \pm$ & $43.2 \pm 0.03$ & $43.5 \pm 0.02$ & $44 \pm 0.02$ & $50.4 \pm 0.02$ & $39 \pm 0.06$ & $34.8 \pm 0.09$ & $37.5 \pm 0.07$ \\
$0.1 \pm$ & $46 \pm 0.01$ & $47.6 \pm 0.0$ & $53.7 \pm 0.04$ & $56 \pm 0.06$ & $43.4 \pm 0.03$ & $36.9 \pm 0.07$ & $42.3 \pm 0.03$ \\
$0.2 \pm$ & $43 \pm 0.03$ & $49.2 \pm 0.01$ & $56.8 \pm 0.06$ & $58.9 \pm 0.08$ & $48 \pm 0.003$ & $37.5 \pm 0.07$ & $45.5 \pm 0.01$ \\
$0.4 \pm$ & $41 \pm 0.04$ & $50.5 \pm 0.02$ & $57.8 \pm 0.07$ & $68.6 \pm 0.14$ & $48 \pm 0.003$ & $82 \pm 0.2$ & $99.5 \pm 0.3$ \\
\hline
\end{tabular}

Table 6: Effect of soil type on $\mathrm{IC}_{50}$ of oil extract

\begin{tabular}{|c|c|c|c|c|c|c|}
\hline 1 & $\begin{array}{l}\text { Soil types } \\
\text { standard }\end{array}$ & & & $\begin{array}{l}\text { DPPH } \\
I_{50}\end{array}$ & 3 & $\begin{array}{l}\text { ABTS } \\
I_{50}\end{array}$ \\
\hline 4 & $\mathrm{ST}_{0}$ & & & 1.196 & 6 & 3.590 \\
\hline 7 & $\mathrm{ST}_{1}$ & & & 1.422 & 9 & 0.328 \\
\hline 1 & $\mathrm{ST}_{2}$ & & 1 & 1.534 & 12 & 0.147 \\
\hline 1 & $\mathrm{ST}_{3}$ & & 4 & 1.594 & 15 & 0.067 \\
\hline 16 & $\mathrm{ST}_{4}$ & & 7 & 1.252 & 18 & 0.595 \\
\hline 1 & $\beta$-carotene & & 0 & 0.722 & 21 & - \\
\hline 2 & Vitamin C & & 3 & 0.843 & 24 & 0.843 \\
\hline 2 & BHT & & 6 & - & 27 & 0.945 \\
\hline
\end{tabular}

essential oils. Citronellol and geraniol are well known for defence mechanisms in human physiology [16]. Citronellol has been found to possess herbicidal activities as well [21]. The possession of novel modes of action in Citronellol (responsible for herbicidal activities) differs from that of synthetic herbicides. These synthetic herbicides persist in the environment long after their application, however, the nonpersistence of Citronellol has led to its adoption in the Generally Regarded as Safe (GRAS) category by the United States Environmental Protection Agency [22]. Furthermore, this compound has been confirmed as a flavouring compound that can be used to synthesise other aroma compounds such as oxides [23]. Its biotransformation can produce large metabolites [24].

\section{CONCLUSION}

The findings of this study indicate that the essential oil of $S$. nigrum shoots is of high quality but slightly differ regarding the different soil textures on which the plant was cultivated. The oil displayed good antioxidant properties which may be due to the presence of geraniol and citronellol (monoterpene alcohols) which are the major compounds present in the oil. Therefore, $S$. nigrum shoots could serve as a possible source of geraniol and citronellol which are basic ingredients in some pharmaceutical formulations.

\section{DECLARATIONS}

\section{Acknowledgement}

This work was supported by National Research Foundation (NRF) South Africa, Govan Mbeki Research Development Centre (GMRDC) of the University of Fort Hare, South Africa; TETFUND, Ladoke Akintola University of Technology, Nigeria and Medicinal Plant; and Economic Development (MPED), University of Fort Hare, South Africa.

\section{Conflict of interest}

No conflict of interest is associated with this work

\section{Contribution of authors}

We declare that this work was done by the author(s) named in this article and all liabilities pertaining to claims relating to the content of this article will be borne by the authors. Adijat Funke Ogundola is the PhD student that carried out the experiment, collected and analysed the data and wrote the manuscript. Dr Callistus Bvenura is the co-supervisor that supervised the practical aspect and guided on the writing up of the manuscript. Prof Anthony Jide Afolayan is the major supervisor that conceived and designs the study. He also sourced for fund to carry out the Research and read the manuscript. In addition, a declaration of the role of each author mentioned 
in the manuscript should be provided. The author who conceived and designed the study, the person(s) who collected and analysed the data, and the person who wrote the manuscript as well as an indication that all authors read and approved the manuscript for publication must be specified

\section{Open Access}

This is an Open Access article that uses a funding model which does not charge readers or their institutions for access and distributed under the terms of the Creative Commons Attribution License (http://creativecommons.org/licenses/by/ 4.0) and the Budapest Open Access Initiative (http://www.budapestopenaccessinitiative.org/rea d), which permit unrestricted use, distribution, and reproduction in any medium, provided the original work is properly credited.

\section{REFERENCES}

1. Wannang NN, Anuka JA, Kwanashie HO (2008) Antiseizure activity of the aqueous leaf extract of Solanum nigrum linn (solanaceae) in experimental animals. Afr Health Sci 8: 74-79.

2. Krishnaiah $D$, Sarbatly $R$, Nithyyanandam $R$ (2011) $A$ review of the antioxidant potential of medicinal plant species. Food Bioprod Process 89: 217-233.

3. Laszczyk MN (2009) Pentacyclic triterpenes of the lupane, oleanane and ursane group as tools in cancer therapy Planta Med 75: 1549-1560. [PubMed]

4. Angioni AA, Barra V, Coronco S, Dessi Carbras P (2006) Chemical composition, seasonal variability and antifungal activity of Lavandula stoechas L. spp. stoechas essential oils from stem/ leaves and flowers. J Agric Food Chem 54: 4364-4370.

5. Lester RN, Peter-Martin LJ, Alan C (2011) Solanum in Africa. Classification, types and their locations. A PhD thesis Peter Jaeger at Birmingham University.

6. Elujoba AA, Odeleye OM, Ogunyemi CM (2005) Traditional Medica Development for medical and Dental primary Health Care Delivery System in Africa. Afr J Trad Compl Alter Med 2(1):46-61.

7. Bhalla Y, Gupta Vk and Jaitak V (2013) Anticancer activity of essential oils: A review. J Sci Food Agric. 93: 3643-365.

8. Dhellot JR, Matouba E, Maloumbi MG, Nzikou JM, Dzondo MG (2006) Extraction and nutritional properties of Solanum nigrum L seed oil. Afr J Biotechnol 5: 987991.

9. Andrade EHA, Alves CN, Guimarães EF, Carreira LMM, Maia JGS (2011) Variability in essential oil composition of Piper dilatatum LC Rich. Biochem Syst Ecol 39:669675.

10. United States Department of Agriculture (2014) Retrieved August 30 63-65.
11. Agricultural Laboratory Association of Southern Africa (AGRILASA) 2008 Method 612: Wet ashing. Plant and feed analysis handbook.

12. Oyedeji AO, Afolayan AJ (2006) Chemical composition and antibacterial activity of the essential oil isolated from South African Mentha longifolia ( $L$ ) L subsp capensis (Thunb) Briq Journal of Essential Oil Research 18: 5759.

13. Odeyemi SW, Afolayan AJ, Brandley G (2016) Comparative study of the anti-diabetic, cytotoxicity and mechanisms of action of Albuca bracteata (Jacq) and Albuca setosa (Jacq). PhD thesis submitted to the Department of Biochemistry and Microbiology, University of Fort Hare, South Africa.

14. Kibiti CM, Afolayan JA (2015) Preliminary Phytochemical Screening and Biological Activities of Bulbine abyssinica Used in the Folk Medicine in the Eastern Cape Province, South Africa. Evidence-based Complem Altern Medicine Article ID 617607, 12 pp.

15. Oyedeji OA, Yani VV, Afolayan AJ (2005) Chemical composition of the essential oil from Arctotis arctotoides (LF) O Hoffm (syn Vendium arctotoides Less). Flavour Fragr J 20: 232-234.

16. Akhila A (2006) Essential Oil-Bearing Grasses, The genus Cymbopogon; Medicinal and Aromatic PlantsIndustrial Profiles, CRC Press, New York.

17. Dudareva N, Negre F, Nagegowda DA, Orlova I (2006) Plant volatiles, recent advances and future perspectives. Crit. Rev. Plant Sci 25: 417 - 440.

18. Singh HP, Kaur SK, Mittal S, Batish DR, Kohli RK. Essential oil of Artemisia scoparia inhibits plant growth by generating reactive oxygen species and causing oxidative damage. J. Chem. Ecol, 2009; 35: 154- 162.

19. Carnesecchi SK, Langley F, Exinger F, Gosse FR (2002) "Geraniol, a component of plant essential oils, sensitizes human colonic cancer cells to 5-Fluorouracil treatment," Journal of Pharmacology and Experimental Therapeutics. 301(2): 625-630.

20. kim Sh, Bae hC, Park EJ, Lee CR, kim BJ, Lee S, Park hh, kim SJ, So I, kim TW (2011) Geraniol inhibits prostate cancer growth by targeting cell cycle and apoptosis pathways. Biochem Biophys Res Commun 407: 129-134.

21. Kaur S, Singh HP, Mittal S, Batish DR, Kohli RK (2011) Phytotoxic effects of volatile oil from Artemisia scoparia against weeds and its possible use as a bioherbicide. Ind Crop Prod 32: 54 - 61.

22. USEPA (2014) Citronellol Biopesticide Registration Action Document. Office of Pesticide Programmes Biopesticide and Pollution Prevention Division U. S. Environmental Protection Agency, Washington D C USA (PC Code 167004).

23. Boersma YL, Schelting AC, Dröge MJ, Bos, R, Quax WJ (2005) $A$ validated gas chromatographic method for the evaluation of enzymatic enantioselectivity in kinetic resolution applications. J Sep Sci (28)6: 501-505.

24. Onken J, Berger RG (1999) Biotransformation of citronellol by the basidiomycete Cystoderma carcharias

Trop J Pharm Res, April 2021; 20(4): 846 
Ogundola et al

Biotechnol 51(2): 158-163.

Trop J Pharm Res, April 2021; 20(4): 847 